\title{
A Single Blinded Randomized Controlled Clinical Trial on the Efficacy of Ozone Therapy on Breast Cancer-Related Lymphedema
}

\author{
Intsar S. Waked ${ }^{1}$, Samah H. Nagib ${ }^{1} \&$ Mohammed T. A. Omar ${ }^{1}$ \\ ${ }^{1}$ Faculty of Physical Therapy, Cairo University, Giza, Egypt \\ Correspondence: Mohammed Taher Ahmed Omar, Cairo University, Faculty of Physical Therapy, Physical \\ Therapy Department for Surgery, 7 Ahmad Alzayat St., Bain El-sarayat, Giza 12612, Egypt. Tel: \\ 20-101-547-585. E-mail: Dr.Taher_M@yahoo.com/Momarar@cu.edu.eg
}

Received: April 2, 2013 Accepted: June 12, 2013 Online Published: October 22, 2013

doi:10.5539/cco.v2n2p93 URL: http://dx.doi.org/10.5539/cco.v2n2p93

\begin{abstract}
Purpose: The purpose of this study was to evaluate the efficacy of ozone therapy in breast cancer-related Lymphedema (BCRL).

Methods: Sixty patients with BCRL were participated in this study and were randomly assigned to one of two groups. Ozone group received ozone therapy in addition to complex physical therapy for lymphedema consisted of pressure garment, remedial exercise, and skin care, while the control group received complex physical therapy only. Limb volume was measured using water displacement and limb circumference. Skin and subcutaneous thickness were measured using Doppler ultrasound. All measurements were carried out at baseline (0wk) and after 12 weeks (12wk) of intervention.

Results: The clinical and demographic characteristics of both groups were comparable at baseline. The reduction of limb volume tended to decline in both groups. The trend was more significantly pronounced in ozone group than control at $12 \mathrm{wk}(\mathrm{P}<0.05)$. There was significant reduction in skin and subcutis thickness in both groups. The rate of thickness reduction was more observable in the ozone group than the control group.
\end{abstract}

Conclusion: Ozone therapy was found to be an effective adjunctive modality for reducing limb volume and thickness in the women with BCRL.

Keywords: ozone, breast cancer- related lymphedema, doppler ultrasound

\section{Introduction}

Breast cancer is the most common cause of cancer death among women worldwide (Jemal et al., 2011). In Egypt, breast cancer represents $18.9 \%$ of total cancer cases admitted to the Egyptian National Cancer Institute (Elatar, 2002; Ibrahim, 2002).

Breast cancer-related lymphedema (BCRL) is a common disabling condition in women treated for breast cancer. The prevalence BCRL is between $12 \%$ and $28 \%$ (Meric et al., 2002; Ozaslan \& Kuru, 2004; Clark, Sitzia, \& Harlow, 2005). This variation can be explained in part by differences in the criteria used to define and diagnosis lymphedema (Quirion, 2010; Jain, Danoff, \& Paul, 2010; Petrek \& Heelan, 1998).

BCRL is a serious condition that often causes pain and disability and can predispose patients to life-threatening complications, such as, infection, limitation of function, loss of body image and self-esteem, affective disorders and fear (Bumpers, Best, \& Norman, 2002; Harris, Hugi, \& Olivotto, 2001). Physical morbidity following BCRL included decreased shoulder mobility and neural tissue injury causing sensory and motor dysfunction. All lead to diminished quality of life and limitations in activities of daily living of the upper limbs (Calitchi et al., 2001; Fehlauer et al., 2003; Leidenius, Leppanen, Krogerus, \& Von Smitten, 2003; Soran et al., 2006; Gosselink et al., 2003; Lee et al., 2007; Ververs et al., 2001).

Lymphedema affects the skin and underlying tissue. The edema usually epifascial that is, outside the fascial bounding the arm musculature, mainly in the subcutis, and the degree of swelling correlate with the increase in thickness of both subcuits and skin (Collins, Mortimer, D'Ettore, A'Hern, \& Moskovic, 1995). A recent study showed that, within the cutaneous structures, the number of fibroblasts, neutrophils and histocytes increased significantly, resulting in hyperkeratosis, edema of the epidermis. Moreover, in the case of chronic lymphedema, 
increase adiposity and collagen deposition is marked. This persistent swelling resulting in inflammation that causes fibrosis, and predispose to infection and reduce immune function locally (Tabiazar, Chueng, Han, Swanson, \& Belhack., 2006; Rockson, 2009).

Current treatment for BCRL is controversial (ISL, 2009). Several therapeutic options have been provided, such as compression garments or bandaging, manual lymphatic drainage (MLD), complex decongestive therapy (CDT), pneumatic compression pump, exercises (Partsch, Stout, \& Forner-Cordero, 2010; Andersen, Hojris, Erlandsen, \& Andersen, 2000; Badger, Peacock, \& Mortimer, 2000; Guerreiro, Oliani, \& Pereira, 2010). More recently low level laser therapy has been used, however, the results of these therapies vary widely and are inconsistent (Dirican et al., 2010; Omar, Ebid, \& El Morsy, 2011; Carati, Anderson, Gannon, \& Piller, 2003).

Recent research suggests that lymphedema might be improved by high-pressure oxygen therapy. The use of oxygen might stimulate the growth of new lymphatic channels and reduction of the scar tissues surrounding existing lymphatic channels leading to reduction of limb volume (Teas et al., 2004; Gothard et al., 2010). Ozone is a naturally-occurring configuration of three oxygen atoms best known for its protective role in the earth's ecological harmony, possesses unique properties, which are being defined and applied to biological systems as well as to clinical practice. As a molecule containing a large excess of energy, ozone manifests bactericidal, virucidal and fungicidal actions that might make it a treatment of choice in certain conditions and an adjunctive treatment in others (Sunnen, 2005; Young \& Setlow, 2004). Ozone reacts with blood generates pharmacological messengers such as hydrogene peroixde $\left(\mathrm{H}_{2} \mathrm{O}_{2}\right)$ and lipid oxidation products (LOPs) these activate several biochemical pathways in blood cells, which are responsible for therapeutic activities lasting several days. The result is improved red blood cell oxygen delivery, activated white blood cell immune response, platelet release of growth factors, endothelial release of nitrous oxide, release of stem cells from the bone morrow and the upregulation of antioxidant enzymes in the various organs (Bocci, 2007). Some recent studies demonstrated that, ozone significantly increases the amount of platelet-derived growth factor (PDGF), transforming growth factor b1 (TGF-b 1) and interleukin-8 (IL-8). These factors are released in a dose-dependent manner and consider as proinflammatory and enhance angiogenesis of lymphatic vessels (Kim et al., 2009; RE et al., 2010).

There are several methods of ozone administration, rectal insufflation is "95\% as effective as blood methods known as "Major Autohemotherapy". It appeared as a safe minimally invasive, painless and reasonable application for treating wide variety of health problems including chronic colitis and fistulae, arterial circulatory disorders, adjuvant cancer therapy. In rectal insufflations, the ozone gas is infused rectally through a urethral catheter, following a bowel movement or a colonic treatment in order to ensure the colon is relatively free of fecal matter. The ozone enters the lower intestine, is held for at least 30-40 minutes ensuring maximum absorption by the body (Carpendale, Freeberg, \& Meleod, 1993; Martınez-Sanchez, Al-Dalain, Menendez, 2005; Li et al., 2007; RE et al., 2007; Guanche et al., 2010; Zaky, Fouad, \& Kotb, 2011; Artis, Aydogan, \& Sahin, 2010; Knoch \& Klug, 1990).

The insufflation of a volume of 200-250 $\mathrm{ml}$ of gas into the rectum/colon at an $\mathrm{O}_{3}$ concentration ranging from 5 to $35 \mu \mathrm{g} / \mathrm{ml}$ can be precisely done but the effective $\mathrm{O}_{3}$ dose is unpredictable because of possible flatulence and the presence of a more or less abundant luminal content (Bocci, Zanardib, Borrellic, \& Travaglib, 2011). However, the correct range of therapeutically useful ozone concentrations has been accurately determined and varies between 10 and $80 \mu \mathrm{g} / \mathrm{ml}$ (Travagli, Zanardi, Silvietti, \& Bocci, 2007).

The pathological correlates of the response to oxygen/ozone in irradiated tissues have been studied in animals, and include neovascularization, organization and marked reductions in fibrous tissue (RE, Martinez-Sanchez, Perez-Davision, \& Sirito, 2010). However, it is not currently clear how these relate to the clinical effects reported in humans. Therefore, the purpose of this prospective, single-blinded, randomized controlled trial was to investigate the efficacy of ozone therapy in the management of BCRL among women with breast cancer therapy.

\section{Methods}

\subsection{Subjects}

Seventy four females were recruited from the surgical department at National Cancer Institute, Cairo, Egypt, between September 2010 and May 2012. All patients had been undergoing unilateral breast cancer surgeries. Subjects who fulfilled the following criteria were eligible for enrollment in the study; (1) unilateral BCRL, (2) mild to moderate lymphedema defined as circumferential difference of 2-8 $\mathrm{cm}$ across 3 sites (Omar et al., 2011), and /or a volume difference of 200-750ml between the upper limbs (Carati et al., 2003; Lau \& Cheing, 2009; Piller, 2000; Piller \& O’Connor, 2002; Petrek et al., 2001; Wilke, McCall, \& Posther, 2006). All patients signed an informed consent before participation in the study. 
Patients were excluded if they had (1) local recurrent or distant metastases, cellulites, chronic inflammatory diseases, (2) medication that influences body fluid and electrolyte balance, (4) history of physical therapy other than skin care, and bandaging directed to lymphedema within the previous six months (Omar et al., 2011; Carati et al., 2003; Teas et al., 2004; Gothard et al., 2010). Patients with bilateral lymphedema were also excluded because the contralateral normal limb was needed to predicate percentage of lymphedema (Omar et al., 2011; Carati et al., 2003; Teas et al., 2004; Gothard et al., 2010).

All subjects were participated in single blinded, randomized, controlled trial. To avoid a type II error, we aimed to recruit 60 participants, giving $80 \%$ power, at $\alpha=0.05$ and effect size $=0.35$ to detect a $14.4 \%$ mean difference in lymphedema between the two groups (Omar et al., 2011). Then we generated a computerized random number list, and the subject allocation sequence was created from the list. The patients met with the evaluator therapist who conducted the assessments. The evaluator therapist was blinded to the group assignment. Following their assessments, the patients were assigned randomly to either ozone or control group. The study was approved by the postgraduate affairs and departmental council. It was registered at an Australian New Zealand Randomized Controlled Trial, No. ACTRN12613000345785.

\subsection{Assessments and Outcome Measures}

All patients were evaluated at the baseline $(0 \mathrm{wK})$ and after the end of 12 weeks of intervention (12wk). A well-trained physical therapist with 12 years of clinical experience was blinded to the groups evaluated all the patients. An absolute change in limb circumference and volume of the affected arm versus unaffected arm and percentage reduction was the primary outcome. Ultrasound imaging was obtained by the blinded radiologist as the secondary outcome measurement.

\subsubsection{Primary Outcome}

Assessment of limb size: Circumference and water-displacement volumetric measurements were used to quantify limb size at each evaluation. Each limb was immersed in a water-filled tank, and the displaced fluid was collected and measured to the nearest milliliters. Circumference was measured every $3 \mathrm{~cm}$ beginning at the ulnar styloid process and continuing $45 \mathrm{~cm}$ proximally, as well as at the metacarpals and mid-hand. Arm volume was then calculated based on the formula for a truncated cone. Each measurement was repeated three times, and the average has been calculated. The correlation between the calculated volume from circumference and total water displacement volume were high $(\mathrm{r}=0.99)$ for both surgical and contralateral upper extremities (Katusic, 1996; Karges, Mark, Stikeleather, \& Worrell, 2003; Sander, Hajer, Hemenway, \& Miller, 2002).

$$
V=h\left(C_{1}^{2}+C_{1} C_{2}+C_{2}^{2}\right) / 12 \pi
$$

Where $\mathrm{V}$ is the volume of the segment, $\mathrm{C} 1$ and $\mathrm{C} 2$ are the circumferences at the ends of the segment, and $\mathrm{h}$ is the distance between them (segment length), $\pi=3.1416$.

The lymphedema volume was determined by comparing the difference in the arm volume between the affected and unaffected arms. Thus, each subject's unaffected arm served as a control. The changes in lymphedema volume were expressed in both milliliters and percentage reduction. The percentage reduction was calculated as follows:

$$
\frac{\text { Differences initial }- \text { Differences at each point of assessment } \times 100}{\text { Difference initial }}
$$

Where difference $=$ affected arm volume-unaffected arm volume.

\subsubsection{Secondary Outcome}

Ultrasound imaging: All measurements were performed in the morning to eliminate the effect of diurnal variation in skin water content on skin thickness and ultrasound echogenicity (Gniadecka, Serup, \& Sondergaard, 1994). Images were obtained using a Sonoline Antares ultrasound system (Siemens, Erlangen, Germany) with a $10 \mathrm{MHz}$ transducer. Ultrasound gel was applied to the skin, and the probe was placed perpendicular to the skin. Images were taken from two sites; (1) twelve $\mathrm{cm}$ down from the supraclavicular joint over the deltoid muscle and (2) ten $\mathrm{cm}$ below the middle of the cubital fossa on inner forearm. The same measurements were taken from the contralateral arm of all patients. The ultrasound unit has built-in software to measure tissue depth. Skin thickness was determined by measuring the distance between the entry echo and the dermis/subcutis boundary. Subcutis thickness was set between the bottom of the dermis, and the line generated by the fascial connective tissue sheet overlying the muscle (Tassenoy et al., 2011; Van der Veen et al., 2001; Mellor et al., 2004). 


\subsection{Therapeutic Intervention}

Ozone therapy Application Using the Rectal Insufflation Method: Before starting the first treatment session, each patient in the study group was instructed carefully about the ozone therapy procedure as well as, its safety, values and effects to gain her confidence and cooperation during the treatment sessions. Furthermore, each patient was advised and instructed to evacuate her bladder and rectum before starting each ozone therapy session.

Each patient assumed a relaxed modified side lying position, then the catheter was held and lubricated with a neutral lubricant (KY gel), and closed by the clamp before inserting it into the rectum through the anus. After that, the syringe was introduced into the free end of the catheter, and the clamp was removed, and the ozone was injected into the catheter, after that, the catheter was closed with the clamp again, to change the syringe. Then each patient received ozone in form of rectal insufflations with ozone concentration of $20 \mu \mathrm{g} / \mathrm{ml}$, increased gradually up to $40 \mu \mathrm{g} / \mathrm{ml}$ and the volume was ranged from $150-300 \mathrm{ml}$. Three syringes of $50 \mathrm{ml}$ were filled with ozone from the portable generator (Ozomed, Kastner Praxisbedarf- D-76437 Rastatt), with total ozone dose of $150 \mathrm{ml}$, with the appropriate concentration was delivered the ozone into the rectum via the catheter in the first session, then the dose and concentration of the ozone were increased gradually in the subsequent sessions to reach the maximum range (ozone dose of $300 \mathrm{ml}$, concentration of $40 \mu \mathrm{g} / \mathrm{ml}$ by using 6 syringes). Finally, the catheter was removed from the patient's rectum, when all the syringes were used. Then each patient was instructed to clean her anus by using sterile dressing and instructed to rest for 5 minutes.

This procedure was increased from three to six times during the study period. As the treatment was administrated three times weekly during the first two month, and two time weekly for the last month (Knoch, Roschke, \& Klug, 1987; Carpendale et al., 1993; Bocci, Borrelli, Corradeschi, \& Valacchi; 2001). Doses were selected taking into account other clinical trials using ozone by rectal insufflations and twenty sessions for ozone rectal application have been suggested (Hernandez Rosales, Calunga Fernandez, Turrent Figueras, 2005; Menendez, Cepero, Borrego, 2008; Martınez-Sanchez, Al-Dalain, \& Menendez, 2005; Copello, Eguia, \& Menendez, 2003), but in this study the number of treatments was increased up to 32 for 12-week period. This treatment scheme was based in the ozone accumulative effect reported by several authors (Bocci, 2002; Hidalgo-Tallon, Menendez-Cepero, Vilchez, Rodriguez-Lopez, \& Calandre, 2012).

All patients were given an education booklet about complex physical therapy included, proper arm care, exercises and self-manual lymph drainage. All patients were given advice to perform daily limb exercise program (Omar, Ebid, \& El Morsy, 2011). Participants were instructed in the skin care to maintain the affected area clean and dry to decrease the risk of infection. All women were instructed to wear pressure garment that provides pressure of (40 to $60 \mathrm{mmHg}$ ), and for $20 \mathrm{~h}$ daily during the period of the study as reported (Omar, Ebid, \& El Morsy, 2011). All patients were given a diary logbook to complete on a daily basis during the intervention period. They were asked to maintain a daily self-report of their daily exercise activities and duration of wearing garment. The content of the logbooks did not differ between ozone group and control groups. The patients in the control group have been seen by the therapist in the initial visit for evaluation and giving instruction about complex physical therapy (CPT), and during the final evaluation. Telephone contact and consultation were available regarding to any complication during the study period.

\subsection{Statistical Analysis}

Statistical analyses of the differences in limb volume, skin and subcutis thicknesses were performed using Statistical Package for the Social Sciences Version 17.0 (SPSS Inc., Chicago, IL, USA). Parametric tests were used to summarize and analyze the primary and secondary outcomes since the data were normally distributed. P-value $<0.05$ was considered to be statistically significant.

\section{Results}

\subsection{Demographic \& Clinical Characteristics}

Figure 1, presents the flow chart for patients throughout the study. Seventy four patients were screened for eligibility, and 68 subjects fulfilled the inclusion criteria, and were initially randomized into two equal groups. Three patients withdrew due to development of cellulites ( 2 in the control group and 1 in the ozone group); two as results of dissatisfaction with ozone therapy, and three reported poor adherence to the treatment ( 2 in the control group and one in the ozone group). Participants with poor adherence to the program (defined as missing more than three consecutive sessions or more than $20 \%$ of all sessions) were excluded from the study, and their data were not used in the statistical analysis. The data were available for 60 patients: control group $(n=30)$, and ozone group $(n=30)$ for the final analysis. Table 1 presents the characteristics of the patients completing the study. Both groups were comparable at the baseline regarding to the demographic and clinical characteristics. 


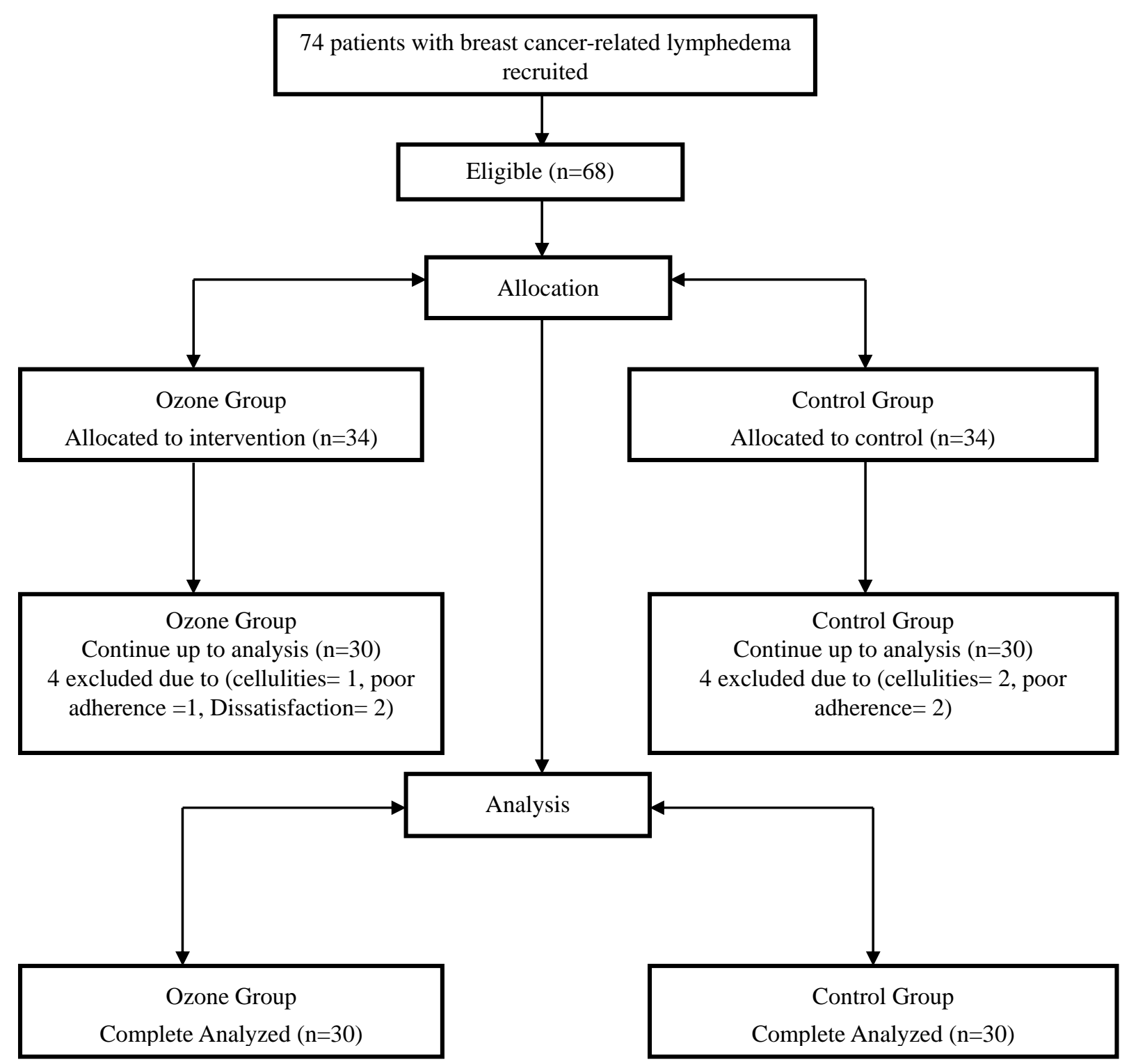

Figure 1. Flow of participants through the study 


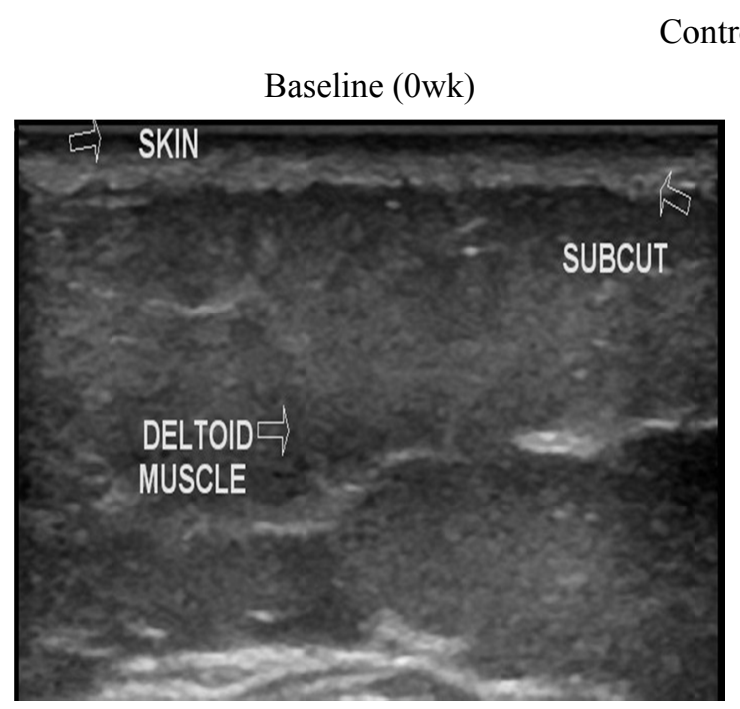

a

Baseline (0wk)

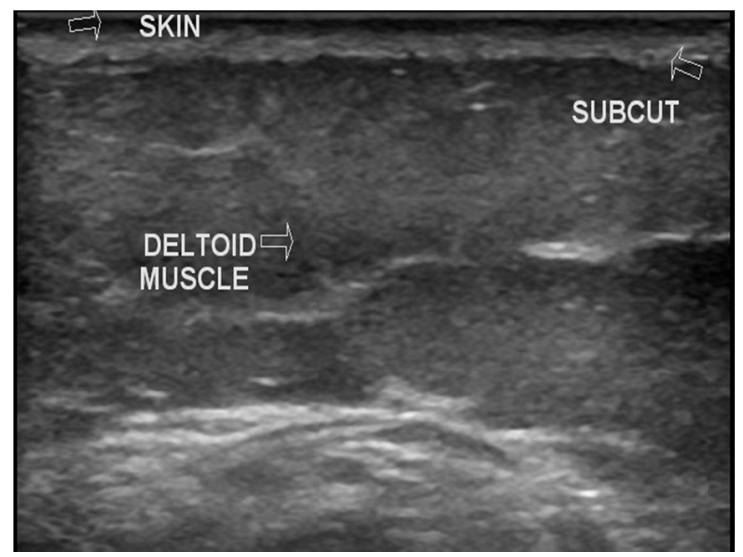

b
After intervention (12wk)

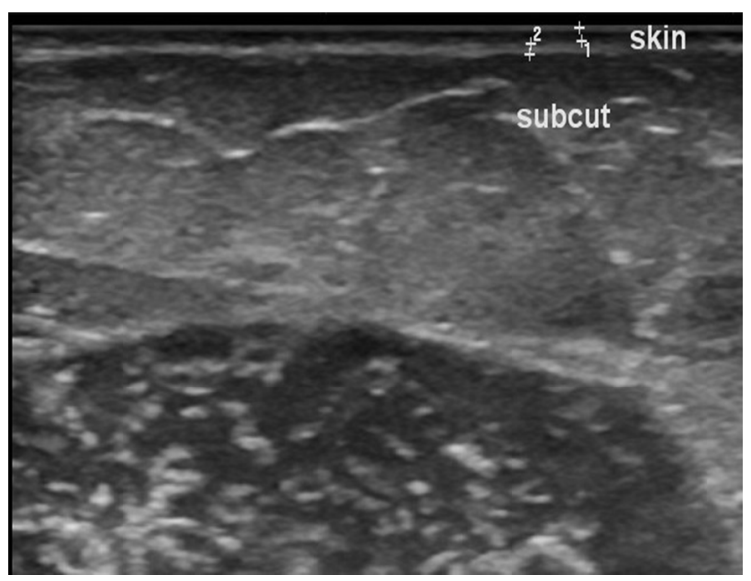

c

Ozone group

After intervention (12wk)

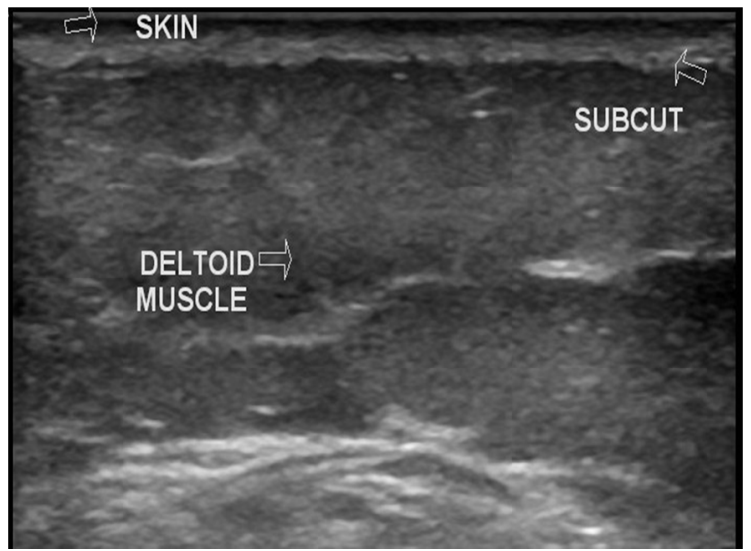

d

Figure 2. Skin and subcutes thickiness $(\mathrm{mm})$ at deltoid level, the increased skin and subcutis thickness is evident at baseline (a \& b). Change in thickness was evident in both control (c), and ozone (d) groups, with more evident in the ozone group

Table 1. Demographic and clinical characteristics of the patients at baseline

\begin{tabular}{lll}
\hline Variables & Ozone group $(\mathrm{n}=30)$ & Control group $(\mathrm{n}=30)$ \\
\hline Age $(\mathrm{years})$ & $54.4 \pm 6.13$ & $53.4 \pm 6.2$ \\
BMI $\left(\mathrm{kg} / \mathrm{cm}^{2}\right)$ & $28.73 \pm 3.22$ & $27.95 \pm 2.57$ \\
Postoperative period (mo) & $17.03 \pm 4.78$ & $16.7 \pm 4.63$ \\
Lymphedema duration (mo) & $11.7 \pm 6.16$ & $12.53 \pm 5.41$ \\
Affected arm N (\%) & & \\
$\quad$ Dominant & $27(90 \%)$ & $28(93.3 \%)$ \\
$\quad 3(10 \%)$ & $2(6.7 \%)$ \\
$\quad$ Non-dominant & & \\
Types of operations N (\%) & $3(10 \%)$ & $3(10 \%)$ \\
$\quad$ RM & & \\
\hline
\end{tabular}




\begin{tabular}{lll}
\hline MRM & $6(20 \%)$ & $9(30 \%)$ \\
SM+ALND & $18(60 \%)$ & $15(50.3 \%)$ \\
BC+ALND & $3(10 \%)$ & $3(10 \%)$ \\
Number of lymph node removed & $13.7 \pm 3.52$ & $12.97 \pm 3.52$ \\
Adjuvant therapy N (\%) & & \\
RT+CT & $9(30 \%)$ & $9(30 \%)$ \\
RT+HT & $15(50 \%)$ & $12(40 \%)$ \\
RT+CT+HT & $12(40.7 \%)$ & $12(40 \%)$
\end{tabular}

There were no statistically significant differences between groups $(\mathrm{P}>0.05)$. Values are mean $\pm \mathrm{SD}, \mathrm{BMI}=$ body mass index, $\mathrm{RM}=$ radical mastectomy, $\mathrm{MRM}=$ modified radical mastectomy, $\mathrm{SM}=$ simple mastectomy, $\mathrm{BC}=$ breast conservative, $\mathrm{ALND}=$ axillary lymph node dissection; RT: radiotherapy; HT: hormonal therapy; CT: chemotherapy.

\subsection{Limb Volume Measurement}

Limb volume measurements are summarized in Table 2, as determined by water displacement and calculated circumference volume. The reductions in volume seen with limb volumetry were observed in control and ozone groups from baseline at $0 \mathrm{wk}$, to subsequent measurement at $12 \mathrm{wk}$. Significant differences were found in milliliter reduction $(224.1 \pm 53.05$ versus $154.21 \pm 45.4, \mathrm{P}<0.05)$ and percentage reduction $(34.1 \pm 4.9 \%$ versus $23.1 \pm 5.42 \%, \mathrm{p}<0.05)$ between ozone and control groups after intervention.

Table 2. Limb volume measurements $(\mathrm{mml})$ in both groups

\begin{tabular}{lllll}
\hline \multirow{2}{*}{ Time of evaluation } & \multicolumn{4}{c}{ Limb volume } \\
\cline { 2 - 5 } & \multicolumn{2}{l}{ Water displacement } & \multicolumn{3}{c}{ Circumference calculating } \\
\cline { 2 - 5 } & Ozone group & Control group & Ozone group & Control group \\
\hline 0wk (baseline volume) & $658.5 \pm 62.12$ & $667.47 \pm 62.82$ & $653.6 \pm 119.96$ & $668.2 \pm 65.49$ \\
12 wk (final volume) & $434.4 \pm 29.54^{*} \dagger$ & $513.26 \pm 47.84^{*}$ & $447.3 \pm 78.84 *$ & $524.27 \pm 52.02^{*}$ \\
Milliliter reduction & $224.1 \pm 53.05 \dagger$ & $154.21 \pm 45.4$ & $206.3 \pm 73.81 \dagger$ & $144.33 \pm 22.4$ \\
$\%$ Reduction & $34.1 \pm 4.9 \dagger$ & $23.1 \pm 5.42$ & $31.56 \pm 7.07 \dagger$ & $21.59 \pm 4.37$ \\
\hline
\end{tabular}

$* P<0.05$ compared with baseline within group, $\quad \dagger P<0.05$ compared between groups.

Limb volume calculated by circumference had a significant reduction within each group from baseline at $0 \mathrm{wk}$, to subsequent measurement at $12 \mathrm{wk}$. Ozone group had a greater decline in milliliter reduction (206.3 \pm 73.81 versus $144.33 \pm 22.4, \mathrm{P}<0.05)$ and percentage reduction $(31.56 \pm 7.07 \%$ versus $21.59 \pm 4.37 \%, \mathrm{P}<0.05)$ compared to the control group.

Correlation between water volumetry and the calculated circumference volume showed a significant correlation between the two methods at baseline $(0 \mathrm{wk})(\mathrm{r}=0.94, \mathrm{p}=0.05)$ and final lymphedema volume measurements (12wk) $(\mathrm{r}=95, \mathrm{p}=0.05)$.

\subsection{Ultrasound Images}

\subsubsection{Dermis Thickness}

Table 3 summarizes the values of dermis and subcutis thickness in both groups. There were no significant differences in the dermis thickness at the deltoid and forearm between both groups at $0 \mathrm{wk}(\mathrm{p}>0.05)$. However, there was a significant increase in dermal thickness at deltoid $(2.24 \pm 0.19,2.32 \pm 0.21$ and $1.29 \pm 0.19)$ and forearm $(2.16 \pm 0.19,2.12 \pm 0.19$ and $1.21 \pm 0.19)$ in both groups compared with unaffected limb $(p<0.05)$. The dermal thickness was significantly decreased in both groups $(\mathrm{P}<0.05)$ after intervention at $12 \mathrm{wk}$. Where, the ozone group had a greater decreased of dermal thickness at deltoid $(19.19 \%$ versus $10.77 \%, \mathrm{p}<0.05)$ and at forearm $(17.59 \%$ versus $9.9 \%, \mathrm{p}<0.05)$ compared with the control group. However, the dermal thickness was still higher in both groups compared with unaffected arm. 
Table 3. Mean thickness $(\mathrm{mm})$ of dermal and subcutis in the upper arm and forearm

\begin{tabular}{|c|c|c|c|c|c|}
\hline & \multicolumn{2}{|c|}{ Ozone group Affected $(n=30)$} & \multicolumn{2}{|c|}{ Control group Affected $(n=30)$} & \multirow{2}{*}{ Unaffected } \\
\hline & 0wk & $12 \mathrm{wk}$ & 0wk & $12 \mathrm{wk}$ & \\
\hline \multicolumn{6}{|l|}{ Dermal thickness } \\
\hline Deltoid & $2.24 \pm 0.19$ & $1.81 \pm 0.12^{* \dagger}$ & $2.32 \pm 0.21$ & $2.07 \pm 0.19^{*}$ & $1.29 \pm 0.19^{\ddagger}$ \\
\hline Forearm & $2.16 \pm 0.19$ & $1.78 \pm 0.26^{* \dagger}$ & 2. $12 \pm 0.19$ & $1.91 \pm 0.19^{*}$ & $1.21 \pm 0.2^{\mathrm{t}}$ \\
\hline \multicolumn{6}{|c|}{ Subcutis thickness } \\
\hline Deltoid & $20.83 \pm 1.94$ & $17.78 \pm 1.75^{* \dagger}$ & $20.91 \pm 2.05$ & $19.1 \pm 1.7^{*}$ & $12.93 \pm 1.9^{\mathrm{t}}$ \\
\hline Forearm & $19.55 \pm 1.93$ & $17.09 \pm 1.51^{* \dagger}$ & $19.71 \pm 2.19$ & $18.19 \pm 1.72^{*}$ & $12.11 \pm 2.05^{\mathrm{t}}$ \\
\hline
\end{tabular}

\subsubsection{Subcutis Thickness}

There were no significant differences in the subcutis thickness at the deltoid and the forearm between both groups 0wk ( $>0.05)$. However, the subcutis thickness at the deltoid $(20.83 \pm 1.94,20.91 \pm 2.05$ and $12.93 \pm 1.9)$ and at the forearm $(19.53 \pm 1.93,19.71 \pm 2.19$ and 12.11 \pm 2.05$)$ was significantly increased in both groups compared with unaffected limb $(\mathrm{p}<0.05)$. The ozone group had a greater decreased of subcutis thickness at deltoid $(14.64 \%$ versus $8.65 \%, \mathrm{p}<0.05)$ and at forearm $(12.58 \%$ versus $7.71 \%, \mathrm{p}<0.05)$ when compared with the control group. However, the subcutis thickness still was higher in both groups compared with unaffected arm.

\section{Discussion}

The purpose of this study was to investigate the efficacy of administration of ozone therapy as a new trend of treatment for the women with breast cancer-related lymphedema.

The results of this study demonstrated a significant effect of ozone therapy on limb thickness and volume in the women with breast cancer-related lymphedema. There were noticeable reductions in the percentage of limb volume measured by circumferences and volumetric methods respectively. The echographic studies showed a significant reduction in the thickness of dermis and subcutis tissues.

To our knowledge, this is a first randomized clinical trial studied the effect of ozone therapy on lymphedema. However, oxygen as adjuvant modalities has been used in form of hyperbaric therapy for treatment of breast cancer lymphedema (Teas et al., 2004; Gothard et al., 2010; Gothard, Stanton, \& MacLaren, 2004). Those authors suggest that hyperbaric oxygen therapy for women with BCRL might be beneficial for reduction of lymphedema, particularly of the hand. Their protocol was well tolerated by the patients, as all patients completed the treatment protocol. They concluded that hyperbaric oxygen therapy was acceptable to lymphedema patients.

As, ozone therapy has been used as an adjuvant therapy in many vascular disorders such as ischemia of lower limbs, severe Raynaud's syndrome, obliteratives atheromatosis (Frankum \& Katelaris, 1993; Tylicki, 2001; Tafil-Klawe, 2002; Cooke, 1997), peripheral occlusive arterial disease (Giunta, 2001) placenta insufficiency (Andikyan, 2000) and other vascular diseases (Bulmer, Bolton, \& Pockley, 1997).

The mechanisms to explain the effect of ozone therapy on lymphedema are still unclear. However, the explanation is the ability of ozone therapy to syntheses and realizes several vasodilating factors, such as the nitric oxide (NO), and endothelium-derived hyperpolarizing factor (EDHF), simultaneously with inhibition of endothelin-1-release. These enhance vasodilatations and improve vascularity with subsequent reduction of lymphedema (Mukhina, Dudina, Yakovleva, \& Zhemarina, 2005).

Moreover, Katusic (1996) reported that ozone can regulate blood vessel's tone, In addition, ozone therapy is known to up-regulate the synthesis of antioxidants in blood, as well as the release of platelet-derived growth factor (PDGF), transforming growth factor beta (TGF- beta) and vascular endothelial growth factors (VEGF) and vascular endothelial growth factors-C (VEGF-C) which stimulates the formation of new lymph vessels (Valacchi \& Bocci, 2000; Biedunkiewicz, Tylicki, Nieweglowski, \& Bumkowski 2004; Lohela, Saaristo, Veikkola, \& Alitalo, 2003). This has been supported by work of Yoon, Murayama and Gravereaux (2003) who reported that transfer of VEGF-C to animals with lymphedema caused a reduction in both thickness and volume of the swelling. So the authors suggested that, the possible reduction of lymphedema secondary to breast cancer treatment might result from down-regulation of VEGF-C-associated geneses. 
Furthermore, Peretyagin, Vorobyo, Strouchkov and Peretyagina (2005) reported significant vasodilatation and decreased total peripheral resistance in the arterioles and pre-capillary sphincters due to release of endogenous prostaglandin-E1 secondary to ozone therapy. This enhances improvement of peripheral circulation.

The increase tissue thickness may be due to deterioration of lymphatic drainage secondary to impaired contractility in lymphatic collectors in subfascial tissue (Modi, Stanton, Levick, \& Mortimer, 2004). Moreover, fibrosis and contraction of scar tissues cause progressive lymphatic obstruction. These cause an imbalance between capillary filtration and lymphatic drainage, with subsequent accumulation of fluid at dermal tissue level and tissue fibrosis at subcutis level (Stanton, Levick, \& Mortimer; 1996; Modi et al., 2004).

Oxygen therapy might enhance stimulation of new lymphatic channels formation known as lymphangoigensis that causes fluid evacuation and enhancement of lymphatic drainage. Moreover, causes reduction of scar tissues surrounding existing lymphatic obstruction leading to reduction of tissue thickness as well as limb volume (Marx, 1994; Teas et al., 2004; Gothard et al., 2010). However, it is not currently clear how these relate to the clinical effects in humans, as this study did not investigated the effect of ozone on lymphatic dynamic and constituent of edematous tissue.

Strength of the current study might be due to use of variety of accurate and reliable outcome measures. The water displacement and circumference measurements were significantly correlated $(\mathrm{r}=0.95)$ and showed reliable results, particularly when used in the same manner by the same operators. Moreover, there was an agreement with previous studies that reported significant correlation between two methods (Karges et al., 2003; Sander et al., 2002).

Ultrasound imaging is a safe, readily available, noninvasive technique. The use ultrasonography in this study provides more supports and objectivity to the results and gives information on the composition of the dermis and subcutis. In this study, the baseline findings of ultrasound imaging showed thickening of the dermis in all patients, with a decrease in echogenicity, which revealed a significant increase in the thickness of the subcutaneous tissue compared with unaffected arm. This has been reported in other echographic studies (Haaverstad, Nilsen, Myhre, Saether, \& Rinck, 1992; Hadjis, Carr, \& Banks, 1985; Ostbye, Pamereau, \& Speechley, 1995; Seidell, Verschuren, \& Kromhout, 1995). It is unlikely that the increase in subcutis (or skin) thickness is due an increase in fluid and/or overgrowth of fibrous and fatty tissue. Following ozone therapy there was a significant finding of reduced skin thickness when compared to the control group, however, it still significant higher in both groups compared to the unaffected arm.

Limitation of this study may be attributed to small simple size so generalization of the results still questionable. So, Prospective randomized controlled studies with a larger sample size are needed to understand the efficacy of ozone therapy in the treatment of BCRL. Further studies on the ozone therapy should be taken to determine the optimal physiologic effects and methods of administration to obtain the most appropriate clinical response. Moreover, further studies are required to explore the long term follows up in order to establish the cost-effectiveness of this approach within the lymphedema treatment program. Another limitation is that contacted with study subject differed between groups. Patients in the control group contacted at baseline and at times of follow up. However, the dairy logbook did not significantly differ between two groups.

\section{Conclusion}

In conclusion, the ozone therapy may be clinically effective in reducing limb volume and subcutaneous thickness in patients with BCRL. So, ozone therapy could be considered as an adjuvant therapy in addition to gold standard therapy that includes manual lymph drainage, compression garment, and skin care in the treatment of women with breast cancer-related lymphedema.

\section{References}

Andersen, L., Hojris I., Erlandsen, M., \& Andersen, J. (2000). Treatment of breast-cancer-related lymphedema with or without manual lymphatic drainage. Acta Oncol, 39, 399-405. http://dx.doi.org/10.1080/028418600750013186

Andikyan, V. M. (2000). Morphofunctional changes in the placenta after ozone therapy. Bull xp Biol Med, 130(7), 715-8. http://dx.doi.org/10.1007/BF02682114

Artis, A. S., Aydogan, S., \& Sahin, M. G. (2010). The effects of colorectally insufflated oxygen-ozone on red blood cellrheologyinrabbits. Clin Hemorheol Microcirc, 45, 329-336.

Badger, C. M., Peacock, J. L., \& Mortimer, P. S. (2000). A randomized, controlled, parallel-group clinical trial comparing multilayer bandaging followed by hosiery versus hosiery alone in the treatment of patients with 
$\begin{array}{llllll}\text { lymphedema } & \text { of } & \text { the } & \text { 2832-2837. }\end{array}$ http://dx.doi.org/10.1002/1097-0142(20000615)88:12<2832::AID-CNCR24>3.0.CO;2-U

Biedunkiewicz, B., Tylicki, L., Nieweglowski, T., \& Bumkowski, S. (2004). Clinical efficacy of ozonated autohaemotherapy in haemodialyzed patients with intermittent claudication: an oxygen-controlled study. Int $J$ Ariif Organs, 27, 29-34.

Bocci, V. (2002). Oxygen-Ozone Therapy. A critical evaluation. AH Dordrecht, The Netherlands: Kluwer Academic Publishers, pp.243-341. http://dx.doi.org/10.1089/acm.2011.0739

Bocci, V. (2007). Scientific and medical aspect of ozone. Arch Med Res, 38, 265-267. http://dx.doi.org/10.1111/j.1365-2672.2008.04141.x

Bocci, V., Aldinucci, C., Borrelli, E., Corradeschi, F., Diadori, A., Fanettid, G., \& Valacchia, G. (2001). Ozone in medicine. Ozone Science \& Engineering, 23, 207-217. http://dx.doi.org/10.1186/2045-9912-1-6

Bocci, V., Zanardib, I., Borrellic, E., \& Travaglib, V., (2011). Reliable and effective oxygen-ozone therapy at a crossroads with ozonated saline infusion and ozone rectal insufflation. Journal of Pharmacy and Pharmacology, 64, 482-489. http://dx.doi.org/10.1111/j.2042-7158.2011.01427.x

Bulmer, J., Bolton, A. C., \& Pockley, C. F. (1997). Effect of combined heat, ozonation and ultraviolet irradiation (VasoCare) on heat shock protein expression by peripheral blood leukocyte populations. $J$ Biol Regul Homeost Agents, 11(3), 104-10.

Bumpers, H. L., Best, I. M., \& Norman, D. (2002). Debilitating lymphedema of the upper extremity after treatment of breast cancer. Am $J$ Clin Oncol, 25, 365-67. http://dx.doi.org/10.1097/00000421-200208000-00009

Calitchi, E., Kirova, Y. M., Otmezguine, Y., Feuilhade, F., Piedbois, Y., \& Le Bourgeois J. P. (2001). Long-term results of neoadjuvant radiation therapy for breast cancer. Int $J$ Cancer, 96, 253-9. http://dx.doi.org/10.1002/ijc.1024

Carati, C. J., Anderson, S. N., Gannon, B. J., \& Piller, N. B. (2003). Treatment of postmastectomy lymphedema with low-level laser therapy: a double blind, placebo-controlled trial. Cancer, 98, 1114-1122. http://dx.doi.org/10.1002/cncr.11641

Carpendale, M. T., Freeberg, J., \& Meleod, J. (1993). Does ozone alleviate AIDS diarrhea? J Clin Gastroenterol, 17, 142-145. http://dx.doi.org/10.1097/00004836-199309000-00010

Clark, B., Sitzia, J., \& Harlow, W. (2005). Incidence and risk of arm oedema following treatment for breast cancer: a three-year follow-up study. Q J Med, 98, 343-348. http://dx.doi.org/10.1093/qjmed/hci053

Collins, C. D., Mortimer, P. S., D'Ettore, H., A'Hern, P. R., \& Moskovic, E. C. (1995). Computed tomography in the assessment of response to lim compression in unilateral lymphedema. Clinical Radiol, 50, 541-544. http://dx.doi.org/10.1016/S0009-9260(05)83188-5

Cooke, E. D. (1997). Treatment of severe Raynaud's syndrome by injection of autologous blood pretreated by heating, ozonation and exposure to ultraviolet light (H-O-U) therapy. Int Angiol, 16(4), 250-4.

Copello, M., Eguía, F., Menéndez, S., \& Menéndez, N. (2003). Ozone therapy in patients with retinitis pigmentosa. Ozone Sci Eng, 25, 223-232. http://dx.doi.org/10.1080/01919510390481540

Dirican, A., Andacoglu, O., Johnson, R., McGuire, K., Mager, L., \& Soran, A. (2011). The short-term effects of low-level laser therapy in the management of breast-cancer-related lymphedema. Support Care Cancer, 19, 685-690. http://dx.doi.org/10.1007/s00520-010-0888-8

Elatar, I. (2002). Cancer registration, NCI Egypt (2001) Cairo, Egypt, National Cancer Institute. Retrieved April 1, 2004, from http://www.jenci-cu.com/article/S1110-0362(12)00058-1/references

Fehlauer, F., Tribius, S., Holler, U., Rades, D., Kuhlmey, A., Bajrovic, A., \& Alberti, W. (2003). Long-term radiation sequelae after breast-conserving therapy in women with early-stage breast cancer: an observational study using the LENT-SOMA scoring system. Int $J$ Radiat Oncol Biol Phys, 55, 651-8. http://dx.doi.org/10.1016/S0360-3016(02)04120-2

Frankum, B., \& Katelaris, C. H. (2003). Ozone therapy in AIDS--truly innocuous. Med J Aust, 159(7), 493.

Giunta, R. (2001). Ozonized autohemotransfusion improves hemorheological parameters and oxygen delivery to tissues in patients with peripheral occlusive arterial disease. Ann Hematol, 80(12), 745-8. http://dx.doi.org/10.1007/s002770100377 
Gniadecka, M., Serup, J., \& Sondergaard, J. (1994). Age-related diurnal changes of dermal oedema: evaluation $\begin{array}{llllll}\text { by high-frequency ultrasound. } \mathrm{Br} & \mathrm{J} & \text { Dermatol, } & 131, & \text { 849-55. }\end{array}$ http://dx.doi.org/10.1111/j.1365-2133.1994.tb08588.x

Gosselink, R., Rouffaer, L., Vanhelden, P., Piot, W., Troosters, T., \& Christiaens, M. R. (2003). Recovery of upper limb function after axillary dissection. $J$ Surg Oncol, 83(4), 204-11. http://dx.doi.org/10.1002/jso.10271

Gosselink, R., Rouffaer, L., Vanhelden, P., Piot, W., Troosters, T., \& Christiaens, M. R. (2003). Recovery of upper limb function after axillary dissection. $J$ Surg Oncol, 83(4), 204-11. http://dx.doi.org/10.1002/jso.10271

Gothard, L., Haviland, J., Bryson, P., Laden, G., Glove, M., \& Harrison, S. (2010). Randomized phase II trial of hyperbaric oxygen therapy in patients with chronic arm lymphedema after radiotherapy for cancer. Radiotherapy \&Oncology, 97, 101-107. http://dx.doi.org/10.1016/j.radonc.2010.04.026

Gothard, L., Stanton, A., \& MacLaren, J. (2004). Non-randomised phase II trial of hyperbaric oxygen therapy in patients with chronic arm lymphoedema and tissue fibrosis after radiotherapy for early breast cancer. Radiother Oncol, 70, 217. http://dx.doi.org/10.1016/S0167-8140(03)00235-4

Guanche, D., Zamora, Z., Hernandez, F., Mena, K., Alonso, Y., Roda, M., ... Gonzales, R. (2010). Effect of ozone/oxygen mixture on systemic oxidative stress and organic damage. Toxicol Mech Methods, 20, 25-30. http://dx.doi.org/10.3109/15376510903503107

Guerreiro, G. M., Oliani, A. H., \& Pereira, J. M. (2010). Active exercises utilizing a facilitating device in the treatment of lymphedema resulting from breast cancer therapy. Ger Med Sci, 8, 31.

Haaverstad, R., Nilsen, G., Myhre, H. O., Saether, O. D., \& Rinck, P. A. (1992). The use of MRI in the investigation of leg oedema. Eur $J$ Vasc Surg, 6(2), 124-129. http://dx.doi.org/10.1016/S0950-821X(05)80228-2

Hadjis, N. S., Carr, D. H., \& Banks, L. (1985). The role of CT in the diagnosis of primary lymphoedema of the lower limb. Am J Roentgenol, 144, 361-364. http://dx.doi.org/10.2214/ajr.144.2.361

Harris, S. R., Hugi, M. R., \& Olivotto, I. A. (2001). Clinical practice guidelines for the care and treatment of breast cancer. CMAJ, 164, 191-9.

Hernandez Rosales, F. A., Calunga Fernandez, J. L., \& Turrent Figueras, J. (2005). Ozone therapy effects on biomarkers and lung function in asthma. Arch Med Res, 36, 559-554. http://dx.doi.org/10.1016/j.arcmed.2005.04.021

Hidalgo-Tallon, J., Menendez-Cepero, S., Vilchez, J. S., Rodriguez-Lopez, C. M., \& Calandre, E. P. (2012). Ozone Therapy as Add-on Treatment in Fibromyalgia Management by Rectal Insufflation: An Open-Label Pilot Study. $A C M, 18,1-5$.

Ibrahim, A. S. (2002). Cancer profile in Gharbiah, Egypt. Methodology and results. Cairo, Ministry of Health and Population Egypt and Middle East Cancer Consortium, Cairo, Egypt, 2002. Retrieved from http://www.mdpi.com/2072-6694/2/4/1771/pdf

International Society of Lymphology Executive Committee. (2009). The Diagnosis and Treatment of peripheral lymphedema. Lymphology, 42, 51-60.

Jain, M. S., Danoff, J. V., \& Paul, S. M., (2010). Correlation between bioelectrical spectroscopy and perometry in assessment of upper extremity swelling. Lymphology, 43, 85-94.

Jemal, A., Bray, F., Melissa, M., Ferlay, J., Ward, E., \& Forman, D. (2011). Global Cancer Statistics. CA Cancer J Clin, 61, 69-90. http://dx.doi.org/10.3322/caac.20107

Karges, J. R., Mark, B. E., Stikeleather, S. J., \& Worrell, T. W. (2003). Concurrent validity of upper extremity volume estimates: comparison of calculated volume derived from girth measurements and water displacement volume. Phys Ther, 83, 134-145.

Katusic, Z. S. (1996). Superoxide anion and endothelial regulation of arterial tone. Free Radical Biol Med, 20 , 443-448. http://dx.doi.org/10.1016/0891-5849(96)02116-8

Kim, H. S., Noh, S. U., Han, Y, W., Kim, K. M., Kang, H., Kim, H. O., \& Park, Y. M. (2009). Therapeutic effects of topical application of ozone on acute cutaneous wound healing. J Korean Med Sci, 24(3), 368-74. http://dx.doi.org/10.3346/jkms.2009.24.3.368 
Knoch, H, G., \& Klug, W. (1990). Ozone-oxygen therapy in proctology. Ter Arkh, 62, 93-8.

Knoch, H. G., Roschke, W., \& Klug, W., (1987). Ozone oxygen therapy in proctology. OzoNachrichten, 6, 51-70.

Lau, R. W., \& Cheing, G. L. (2009). Managing postmastectomy lymphedema with low-level laser therapy. Photomed Laser Surg, 27, 763-769. http://dx.doi.org/10.1089/pho.2008.2330

Lee, T. S., Kilbreath, S. L., Refshauge, K. M., Pendlebury, S. C., Beith, J. M., \& Lee, M. J. (2007). Pectoral stretching program for women undergoing radiotherapy for breast cancer. Breast Cancer Res Treat, 102(3), 313-21. http://dx.doi.org/10.1007/s10549-006-9339-0

Leidenius, M., Leppanen, E., Krogerus, L., \& Von Smitten, K. (2003). Motion restriction and axillary web syndrome after sentinel node biopsy and axillary clearance in breast cancer. Am J Surg, 185, 127-30. http://dx.doi.org/10.1016/S0002-9610(02)01214-X

Li, L. J., Yang, Y. G., Zhang, Z. L., Nie, S. F., Li, Z., Li, F., ... Guo, Y. B. (2007). Protective effects of medical ozone combined with traditional Chinese medicine against chemically- induced hepatic injury in dogs. World J Gastroenterol, 13, 5989-5994. http://dx.doi.org/10.3748/wjg.13.5989

Lohela, M., Saaristo, A., Veikkola, T., \& Alitalo, K. (2003). Lymphangiogenic growth factors, receptors and therapies. Thromb Haemost, 90, 167-184.

Martınez-Sanchez, G., Al-Dalain, S. M., Menendez, S., Re, L., \& Giuliani, A. (2005). Therapeutic efficacy of ozone medical treatments in patients with diabetic foot. Eur $J$ Pharmacol, 523, 151-161. http://dx.doi.org/10.1016/j.ejphar.2005.08.020

Marx, R. E. (1994). Radiation injury to tissue. In Kindwall Ep (ed), Hyperbaric medicine Practice. Flagstaff Arizona.

Mellor, R. H., Bush, N. L., Stanton, A. B., Bamber, J. C., Levick, J. R., \& Mortimer, P. S. (2004). Dual-frequency ultrasound examination of the skin and subcutis thickness in breast cancer-related lymphedema. Breast J, 10, 496-503. http://dx.doi.org/10.1111/j.1075-122X.2004.21458.x

Menendez, S., Cepero, J., \& Borrego, L. (2008). Ozone therapy in cancer treatment: State of the art. Ozo-Sci Eng, 30, 398-404. http://dx.doi.org/10.1080/01919510802473724

Meric, F., Buchholz, T. A., Mirza, N. Q., Vlastos, G., Ames, F. C., Ross, M. I., \& Pollock, R. E. (2002). Long-term complications associated with breast-conservation surgery and radiotherapy. Ann Surg Oncol, 9, 543-549. http://dx.doi.org/10.1007/BF02573889

Modi, S., Stanton, A. W. B., Levick, J. R., \& Mortimer, P. S. (2004). Treatment of breast cancer dose not impair local lymph drainage in the epifascial and subfascial compartment of the ipsilateral arm. Microcirculation, 11, 547-552. http://dx.doi.org/10.1080/10739680490488634

Mukhina, I., Dudina, E., Yakovleva, E., \& Zhemarina, N. (2005). The dose-dependent effect of ozonated physiological solution on arterial vasodilation. IOA $17^{\text {th }}$ World Ozone Congress, Strasbourg, pp, (III.3.9), $1-8$.

Omar, M. T., Ebid, A., \& El Morsy, A. M. (2011). Treatment of Post-Mastectomy Lymphedema with Laser Therapy: Double Blind Placebo Control Randomized Study. J Surg Res, 165, 82-90. http://dx.doi.org/10.1016/j.jss.2010.03.050

Ostbye, T., Pamereau, J., \& Speechley, M. (1995). Correlations of body mass index in the 1996 Ontario Health Survey. Can Med Assoc J, 152(11), 1811-1817.

Ozaslan, C., \& Kuru, B. (2004). Lymphedema after treatment of breast cance. Am J Surg, 187, 69-72. http://dx.doi.org/10.1016/j.amjsurg.2002.12.003

Partsch, H., Stout, N., \& Forner-Cordero, I. (2010). Clinical trials needed to evaluate compression therapy in breast cancer-related lymphedema (BCRL): proposals from an expert group. Int Angiol, 29, 442-53.

Peretyagin, S., Vorobyo, A., Strouchkov, A., \& Peretyagina, N. (2005). On the mechanisms of correction of systemic, peripheral circulatory and microcirculatory disorders by ozone in critical conditions. IOA 17th World Ozone Congress, Strasbourg, pp (111.3.23)1-9.

Petrek, J. A., \& Heelan, M. C. (1998). Incidence of breast carcinoma-related lymphedema. Cancer, 83(Suppl 12), 2776-81. http://dx.doi.org/10.1002/(SICI)1097-0142(19981215)83:12B+<2776::AID-CNCR25>3.0.CO;2-V

Petrek, J. A., Senie, R. T., Peters, M., \& Rosen, P. (2001). Lymphedema in a cohort of breast carcinoma survivors 
$\begin{array}{lllll}20 & \text { years } & \text { after } & \text { diagnosis. } & \text { Cancer, }\end{array}$ http://dx.doi.org/10.1002/1097-0142(20010915)92:6<1368::AID-CNCR1459>3.0.CO;2-9

Piller, N. (2000). Recognition, treatment and management of a lymphedema arm. Flinder Press, Australia, 152(11), 1811-1817.

Piller, N., \& O'Connor, M. (2002). The Lymphedema Handbook: Causes, Effects \& Management. Hill of Content ( $\left({ }^{\text {nd }}\right.$ Edition). Michelle Anderson, Pty Ltd: Melbourne, Australia.

Quirion, E. (2010). Recognizing and treating upper extremity lymphedema in postmastectomy/lumpectomy patients: a guide for primary care providers. $J$ Am Acad Nurse Pract, 22, 450-9. http://dx.doi.org/10.1111/j.1745-7599.2010.00542.x

RE, L., Martinez-Sanchez, Perez-Davision, G., \& Sirito, M. (2010). Role of Ozone/Oxygen in fibroblast growth factor activation. discovering the facts. International Journal of Ozone Therapy, 9, 55-58.

RE, L., Mawsouf, M. N., Menéndez, S., León, O. S., Sánchez, G. M., \& Hernández, F. (2007). Clinical and basic evidence of ozone therapeutic potential. International Journal of Ozone Therapy, 6, 117-120.

Rockson, S. R. S. (2009). The unique biology of lymphatic edema. Lymph Res Bio, 7, 97-100. http://dx.doi.org/10.1089/lrb.2009.7202

Sander, A. P., Hajer, N. M., Hemenway, K., \& Miller, A. C. (2002). Upper-extremity volume measurements in women with lymphedema: a comparison of measurements obtained via water displacement with geometrically determined volume. Phys Ther, 82, 1201-1212.

Seidell, J., Verschuren, W. M., \& Kromhout, D. (1995). Prevalence and trends of obesity in the Netherlands 1987-1991. Int J Obesity, 19(2), 924-927.

Soran, A., D’Angelo, G., Begovic, M., Ardic, F., Harlak, A., Samuel Wieand, H., \& Johnson, R. R. (2006). Breast cancer-related lymphedema-what are the significant predictors and how they affect the severity of lymphedema? Breast J, 12(6), 536-43. http://dx.doi.org/10.1111/j.1524-4741.2006.00342.x

Stanton, A. W., Levick, J., \& Mortimer, P. S. (1996). Current puzzles presented by postmastectomy oedema (breast cancer related lymphedema). Vas Med, 1, 213-225.

Sunnen, G. (2005). Ozone in Medicine: Overview and Future Directions. Journal of Advancement in Medicine, 1(3), 159-174.

Tabibiazar, R., Cheung, L., Han, J., Swanson, J., Belhack, A., An, A., ... Joshi, S. (2006). Inflammatory manifestation of experimental lymphatic insufficiency. PLoS Med, 3, 254. http://dx.doi.org/10.1371/journal.pmed.0030254

Tafil-Klawe, M. (2002). Ozone therapy and the activity of selected lysosomal enzymes in blood serum of patients with lower limb ischaemia associated with obliterative atheromatosis. Med Sci Monit, 8(7), 520-5.

Tassenoy, A., De Mey, J., De Ridder, F., Schuerbeeck, P. V., Vanderhasselt, T., Lamote, J., \& Lievens, P. (2011), Postmastectomy lymphedema: different patterns of fluid distribution visualized by ultrasound imaging compared with magnetic resonance imaging. Physiotherapy, 79, 234-243. http://dx.doi.org/10.1016/j.physio.2010.08.003

Teas, J., Cunningham, J. E., Cone, L., Jansen, K., Raghavan, S. K., Nitcheva, D. K., \& Tjandra J. J. (2004). Can hyperbaric oxygen therapy reduce breast cancer treatment-related lymphedema? A pilot study. $J$ women Health, 13(9), 1008-1018. http://dx.doi.org/10.1089/jwh.2004.13.1008

Travagli, V., Zanardi, I., Silvietti, A., \& Bocci, V. (2007). A physicochemical investigation on the effects of ozone on blood. Int J Biol Macromol, 41, 504-511. http://dx.doi.org/10.1016/j.ijbiomac.2007.06.010

Tylicki, L. (2001). Beneficial clinical effects of ozonated autohemotherapy in chronically dialysed patients with atherosclerotic ischemia of the lower limbs--pilot study. Int J Artif Organs, 24(2), 79-82.

Valacchi, G., \& Bocci, V. (2000). Studies on the biological effects of ozone: 11. Release of factors from human endothelial cells. Mediators of inflammation, 9, 271-276. http://dx.doi.org/10.1080/09629350020027573

Van der Veen, P. H., Vermeiren, K., Von Kemp, K., Lamote, J., Sacre, R., \& Lievens, P. (2001). A key to understanding postoperative lymphoedema: a study on the evolution and consistency of oedema of the arm using ultrasound imaging. Breast, 10, 225-230. http://dx.doi.org/10.1054/brst.2000.0256

Ververs, J. M., Roumen, R. M., Vingerhoets, A. J., Vreugdenhil, G., Coebergh, J. W., Crommelin, M. A., ... Schijven, M. (2001). Risk, severity and predictors of physical and psychological morbidity after axillary 
lymph node dissection for breast cancer. Eur $J$ Cancer, $37(8), \quad 991-9$. http://dx.doi.org/10.1016/S0959-8049(01)00067-3

Wilke, L. G., McCall, L. M., \& Posther, K. E. (2006). Surgical complications associated with sentinel lymph node biopsy: Results from a prospective international cooperative group trial. Annals of Surgical Oncology, 13(4), 491-500. http://dx.doi.org/10.1245/ASO.2006.05.013

Yoon, Y. S., Murayama, T., \& Gravereaux, E. (2003). VEGF-C gene therapy augments postnatal lmphangiogenesis and ameliorates secondary lymphedema. J Clin Hnvest, 111, 717.

Young, S. B., \& Setlow, P. (2004). Mechanisms of bacillus subtilis spore resistance to and killing by aqueous ozone. J Applied Microbiology, 96(5), 1133-1142. http://dx.doi.org/10.1111/j.1365-2672.2004.02236.x

Zaky, S., Fouad, E. A., \& Kotb, H. M. (2011). The effect of rectal ozone on the portal vein oxygenation and pharmacokinetics of propranolol in liver cirrhosis (a preliminary human study). Br J Clin Pharmacol, 71, 411-415. http://dx.doi.org/10.1111/j.1365-2125.2010.03851.x

Zaky, S., Kotb, H. M., \& Fouad, E. A. (2011). Important details to be clarified about the effect of rectal ozone on the portal vein oxygenation. Br J Clin Pharmacol, $72, \quad 350-35$. http://dx.doi.org/10.1111/j.1365-2125.2011.03973.x

\section{Copyrights}

Copyright for this article is retained by the author(s), with first publication rights granted to the journal.

This is an open-access article distributed under the terms and conditions of the Creative Commons Attribution license (http://creativecommons.org/licenses/by/3.0/). 